\title{
Captain Euro and Citizenship Education: Creating a Comic Book Hero for European Children
}

\section{Lincoln Geraghty, University of Portsmouth}

This critical essay focuses on the notion of identity and examine to what extent the comic book hero, Captain Euro, represents a unified symbol of European citizenship for child readers. Created in 1998 on commission for the EU the Captain Euro comic book storyline was designed to introduce and strengthen European identity and citizenship amongst children in the union. Using digital and online spaces the character was written in a similar vein to the Captain America figure, who himself was introduced to American comic book readers doing World War Two to encourage patriotism and a sense of unity (Fornäs, 2012: 28). The Captain Euro comic book includes various heroes who represent the values and ideals celebrated by the EU, such as unity, intellect, and culture. The villains are intent on discord, breaking up the EU to set up their own empire. These characters rely on certain stereotypes to communicate notions of identity to child readers; as such, the Captain Euro comic is an attempt to educate children in the Union about what it means to be European and united.

Stereotypes are often powerful mechanisms used to label and objectify people from various social, national, racial, and ethnic groups. Their dissemination through contemporary children's media is tied to the production of meaning and the pervasiveness of fear of the unfamiliar and the unknown in an increasingly global society. Through language and the media we get a sense of who we are in opposition to those who we think we are not. The formulation of different types of people and social groups in our minds, or them, creates stereotypes that we use to help unify concepts about $u s$. So, stereotypes may be harmful, often degrading, offensive, and simplistic in their representation of the other but they are important components in the process of social identification and creating a sense of European identity. For Richard Jenkins, "Identity" 
denotes "the ways in which individuals and collectivities are distinguished in their relations with other individuals and collectivities"; "Identification" is "the systematic establishment and signification, between collectivities, and between individuals and collectivities, of relationships of similarity and difference" (2004: 5).

Taken together, similarity and difference are the principles of identification, and are at the heart of the European project: creating unity through diversity. Stereotypes, and therefore the Captain Euro comic book, contribute to this since national identity is formulated through our understanding of who we are as Europeans and individual citizens of member states. If we are to follow John Wall's assertion that contemporary childhood studies must find ways of conceptualising children as individual and social subjects (2013: 69) then my analysis of the Captain Euro project seeks to appreciate how the character and story speak to and frame child readers as European citizens - addressing concerns over identity and social inclusion that remain at the heart of the European project to bring together millions of people from across the continent, speaking different languages and of all ages and nationalities.

\section{From the Euro to European Crisis}

The creation of marketing expert Nicolas De Santis, Captain Euro was originally designed by the British company Twelve Stars Communication to aid in the education and symbolic unification of those European nations who were about to adopt the euro as their currency in 2000. It is ironic that a UK based company was hired to do such a thing since Britain had chosen not to get rid of the pound and the country had been a hotbed of euroscepticism since it officially joined the union in the 1970s. Still, De Santis had mapped out an entire cast of characters and backstories for the Captain Euro team; targeting the use of comics, a website, an animated series, and merchandise to reach young audiences and teach them about how economic unity leads to cultural and political 
harmony (see Kuhn, 2000). While the comic and characters have been analysed in terms of their ideological message and representation of European identity and values in various scholarly accounts (see Fornäs, 2012 and Božić-Vrbančić \& Vrbančić, 2011) I want to discuss here the importance of the relationship between intended child audience and the notion of national identity. Specifically, why might a superhero character be used as a conduit to foster a sense of European identity across a political union that was, and still is, divided along linguistic, cultural, historical and economic lines?

The EU is a community very much in its infancy, joined by "loosely combined 'spheres of publics' - networks of communication" (Fornäs, 2012: 2). With no single centre a sense of identity comes from shared symbols; representing positive aspects of unification. For Anthony P. Cohen "People construct community symbolically, making it a resource and repository of meaning, and a referent of their identity" (1985: 118). Yet, the recent migrant crisis, austerity protests and Brexit vote in the UK suggest the European project is at a turning point and that shared symbols - like the euro - have achieved little in bringing together nation states. Not surprising then that De Santis decided to relaunch Captain Euro and enlist the character in the battle to save the European Union in the face of political upheaval. In 2014 the Captain was rebranded and given a new remit, not just to educate readers in what makes the EU so good but send messages to audiences and politicians about what they should be doing to save Europe from future wars and national conflict. De Santis said in an interview about Euro's reappearance, Together we are one of the world's strongest powers. Separately, we amount to far less in this newly globalized world, where size is everything... Armed with this knowledge, Captain Euro will continue on his heroic mission to promote the values of a united EU which we all share: peace, solidarity and sustainability. (quoted in Mayer, 2014)

In many ways, Captain Euro version 2 represents an evolution of the original mission, staying true to promoting a sense of unity and identity within Europe but also now advertising a 
sense of European strength and diplomatic activism outside of the union, to the world. Building on the didactic message of teaching children about the benefits of a shared currency the rebranded Captain Euro highlights a more "Eurocentric dream” argues Senka Božić-Vrbančić, and Mario Vrbančić (2011: 43). For example, new comic strips released in the build up to the British General Election in 2015 depict the Captain phoning European leaders such as Angela Merkel, David Cameron, Jean-Claude Juncker, and US President Barack Obama, urging them to take action against various threats to the EU: issues including continued British euroscepticism, unfair treatment of member states, and the TTIP (Transatlantic Trade and Investment Partnership). Captain Euro embodies the desire to show young audiences the wonders of European culture - the great capital cities and monuments from across the union - but at the same time he represents Europe as a global superpower, playing an important part in the political and diplomatic processes of international relations.

Where once Euro fought against the likes of villainous billionaire and global developer Dr. D. Vider (notice the name connotes division - the villain's ultimate goal for Europe) he now tackles real political adversaries such as North Korean leader Kim Jong-un and Russia's Vladimir Putin, confronting them about nuclear weapons tests and the unlawful invasion of the Ukraine. More than before Captain Euro is being used to provide child citizens a symbol of not just continental unity but national fortitude against the outsider - the other. Benedict Anderson described the notion of the "imagined community", nations made up of people who can never know all of their neighbors, meet them or hear of them but "in the mind of each lives the image of their communion" (1991: 15). Shared symbols like the euro help build a sense of shared history, culture and nationhood for the community. Yet Captain Euro now offers more to his young audience, he offers a sense of what it stands against. Michael Billig argues this is a form of nationalist thinking where identity is conceived as a binary - us versus them - "... the nation', 
which is said to have its unique destiny (or identity)... the foreigners', from whom 'we' identify ‘ourselves' as different” (1995: 61).

\section{Childhood, Nationhood and Creating a European Identity}

It is perhaps unsurprising that a comic book superhero was chosen as the means through which notions of identity and European citizenship could be mediated. As a medium generally understood to be aimed at children comics have often been used to convey messages of national importance at times of political or social upheaval: "The whole superhero genre is a response to the immigrant experience, and the struggle to adapt to a new national identity" (Brownie and Graydon, 2016: 55). Again, the Captain America example mentioned at the start of this essay suggests that the comic book superhero operates at a deeply nationalistic level, particularly when a country is threatened or feels threatens. In his analysis of the first edition of Captain America, published in 1941 with a picture of the eponymous hero punching Adolph Hitler on the front cover, Christopher Murray argues that such characters and texts represent not only obvious forms of propaganda but also serve to illustrate the contexts for reaffirming national identity in times of crisis (2012: 139). The message is more complex than simple jingoism. The same could be said of Captain Euro's rebranded emphasis on protecting Europe from outside threats and internal political wrangling. Only, in this case, there is no one nation that he is destined to protect and promote; rather, it is the idea of unity through diversity that he must get across to those young citizens who do not yet fully grasp what the EU is and where they fit within it.

Scholarship on the history of children's literature points to the inexorable link between childhood and nationhood. Christopher Kelen and Björn Sundmark state that “children's literature makes and educates future citizens" (2013: 1). The two markers of identity are both "born" in one fashion or the other, suggesting a sense of "origin" and "home" from which 
children can gauge who they are and where they come from. Indeed, Margaret Meek underscores this point, and seems to be drawing parallels with Billig's argument about otherness, when she says that "we have to emphasise the part that children's literature plays in the development of children's understanding of both belonging (being one of us) and differentiation (being other)" (2011: x). However, the process of educating children about what it means to be British, say, or a citizen of the UK, is different to that of teaching children what it means to be a citizen of the EU. While the need to establish devotion from an early age (Kelen and Sundmark, 2013: 3) might be similar in each case there are important differences in that one is a nation and the other a union of nations and one has an established canon of children's literature and media forms that emphasise Britishness and the other struggles to promote a sense of similarity in a sea of differing linguistic and cultural texts. That Captain Euro was created to try and bridge the gap between cultural and linguistic boundaries using a child orientated genre such as the comic book superhero suggests De Santis recognized the importance of children's literature in the formation of a European citizen identity. Yet, knowing the exact cultural forms and texts upon which that identity should be based is an even bigger problem to overcome.

As a political, economic and cultural institution the European Union has striven to create a sense of identity that can be communicated to all member states and European citizens. Yet, at the same time, because of the differences between countries and the attitudes towards sovereignty and federalism, the EU has had to juggle the contradictory opinions about what being European means. As a consequence, it is important to understand that "European identity is a political construction project undertaken by various national and supranational elites" (Checkel and Katzenstein, 2009: 3). Captain Euro is but one strategy used to engage EU child citizens with notions of identity. More obvious symbols and acts such as the flag, currency, anthem and creation of a Euro Day are blended with media texts and events such as Captain Euro and Junior 
Eurovision to offer a more complex interpretation of citizenship; one which acknowledges that even different types of identity are contested within the EU. For example, Furio Cerrutti argues that "there is hardly so confused and polysemic a topic in European affairs as identity", listing five diverse ways identity can be measured, assumed and constructed in the EU: identity as a set of things (eg. security and defence); identity as a set of laws (eg. Constitutional); identity as a substantive definition derived from ethics (eg. the EU as a democracy, caretaker for humanity); identity as a substantive definition derived from historical and philosophical viewpoints (eg. the EU as offspring of the Renaissance and Enlightenment); and identity as a political formulation based on how citizens perceive themselves as Europeans (2008: 3-4).

Identity and citizenship are a complicated messages to get across to children in comic book form - ones that even Captain Euro may struggle to deal with - but perhaps attempts are necessary considering recent research on how children's understanding of European identity is acquired when growing up. Results of a survey of 200 school children aged 8-11 across eight European countries, attempting to determine their grasp of European values and citizenship, show that a common European identity across boarders is a hard thing to define. Marjanca Pergar Kuščer and Simona Prosen's study revealed that "few children understood what the European Union represented" but "most saw themselves as being active citizens in the future" (2005: 2324). A strange dichotomy considering one could argue that a grasp of the former is required for a sense of the latter to develop. The authors go onto to suggest that fostering communication among children would benefit the European community, thus "promote attachment, interdependence and behavioural involvement to the emerging concept of European identity" (25). I would argue this returns us back to Anderson's notion of the "imagined community" and therefore makes the Captain Euro narrative akin to the shared stories and myths of heroism that prove crucial in inspiring people to stand up and declare themselves to be either British, French 
or German. Perhaps the problem for the Captain, however, is that time is too short and his stories of bravery, action and adventure have not had years to embed themselves within the fabric of a shared European popular culture.

In sum, the creation, promotion and evolution of the Captain Euro character and comic book, whether or not he was designed to educate children about the euro or warn them about encroaching threats to the EU, highlights the continued importance of identity within Europe and the pivotal function of children as European citizens. The comic book character has clearly become a contested site for what it means to be European but, even more so, as an educative text it underlines how iterations of children's literature have been continually used to enable and justify structures of ideology and nationhood. Jacqueline Rose, in her seminal study of Peter Pan, argues that "children's literature leads off to the multiple centres of our culture where we rediscover the child being constituted by other institutions and practices in their various forms (education, theatrical history, legislative and social reform)" (1993: 142). Following my analysis of Captain Euro in this essay, I would add media and politics to this list. The reasons behind De Santis's idea for a comic book superhero designed for European children may be construed as cynical, a blatant attempt at constructing a unified national identity where none naturally exists. However, that he felt they needed something to inspire them, to create similarity where difference often dominates, points to the ongoing project of the European Union and the importance of citizenship education through shared a childhood culture in Europe.

\section{Work Cited}

Anderson, Benedict (1991), Imagined Communities. Revised Edition. London: Verso. Billig, Michael (1995), Banal Nationalism. London: Sage.

Božić-Vrbančić, Senka and Vrbančić, Mario (2011), "Captain Euro: Time, Space and Imperial Power." Studia Ethnologica Croatica, 23: 25-46.

Brownie, Barbara and Graydon, Danny (2016), The Superhero Costume: Identity and Disguise in Fact and Fiction, London: Bloomsbury. 
Cerutti, Furio (2008), "Why Political Identity and Legitimacy Matter in the European Union." In The Search for a European Identity: Values, Policies and Legitimacy of the European Union. Eds. Furio Cerutti and Sonia Lucarelli. London: Routledge, 3-22.

Checkel, Jeffrey T. and Katzenstein, Peter J. (2009), "The Politicization of European Identities." In European Identity. Eds. Jeffrey T. Checkel and Peter J. Katzenstein. Cambridge: Cambridge University Press, 1-25.

Cohen, Anthony P. (1985), The Symbolic Construction of Community. Chichester: Ellis Horwood.

Fornäs, Johan (2012), Signifying €urope. Bristol: Intellect.

Jenkins, Richard (2004), Social Identity, Second Edition. London: Routledge.

Kelen, Christopher (Kit) and Sundmark, Björn (2013), "First Things: Introduction." In The Nation in Children's Literature: Nations of Childhood. Eds. Christopher (Kit) Kelen and Björn Sundmark. New York: Routledge, 1-8.

Kuhn, David (2000), "Calling Captain Euro.” Money, 29.3: 28.

Mayer, Catherine (2014), "Is It a Bird? Is It a Plane? No. It's Captain Euro." Time.com.

Meek, Margaret (2001), "Preface." In Children's Literature and National Identity. Ed. Margaret Meek. Stoke on Trent: Trentham Books, vii-xvii.

Murray, Christopher (2012), "Propaganda: The Pleasures of Persuasion in Captain America." In Critical Approaches to Comics: Theories and Methods. Eds. Matthew J. Smith and Randy Duncan. New York: Routledge, 129-141.

Pergar Kuščer, Marjanca and Prosen, Simona (2005), "Different Identities and Primary School Children.” In Emerging Identities Among Young Children: European Issues. Eds.

Panayota Papoulia-Tzelepi, Søren Hegstrup and Alistair Ross. Stoke on Trent: Trentham Books, 9-25.

Rose, Jacqueline (1993), The Case of Peter Pan, of the Impossibility of Children's Fiction. Philadelphia: University of Pennsylvania Press.

Wall, John (2013), "Childism: The Challenge of Childhood to Ethics and the Humanities." In Children's Table: Childhood Studies and the Humanities. Ed. Anna Mae Duane. Athens: University of Georgia Press, 68-84. 